\title{
Should Grammar be Taught?
}

\author{
Ruyun $\mathrm{Hu}$ \\ Chong Qing Normal University, Chong Qing, China \\ Email: veranodeyo@live.cn
}

\begin{abstract}
With the communicative methodology favored in the language teaching beginning in the late 1970s, the helpfulness of formal instruction to grammar teaching in the second or foreign language has been questioned. For instance, in China, many language experts advocate that grammar teaching should be excluded for the purpose of pursuing language learners' communicative competence. Others, however, suspect this statement and demonstrate the opposite point of view. Thus, it is necessary to pay special attention to and show the debated issue related to the explicit grammar teaching through focusing on forms and the implicit teaching through communicative focus. The illustrated discussions related to these issues about the language accuracy and language proficiency will be concerned to that extent.
\end{abstract}

Index Terms - grammar, communicative competence, second language teaching, foreign language teaching

\section{INTRODUCTION}

In the last couple of decades, developing foreign language learners' language proficiency and communicative competence has been demonstrated so that language teaching focuses on enhancing learners' speaking skills as well as communication skills. For instance, skill-based approaches to language teaching have also been highlighted in a sense. Thus, these assumptions have evoked communicative approach through communicative language teaching at the dominated area in the foreign language teaching since it helps language teachers make sense of the innovative techniques and appropriate materials for developing learners' communication skill. Nevertheless, in the late 1970s, with the communicative methodology favoring in the language teaching, the helpfulness of formal instruction to grammar teaching in the second or foreign language has been questioned.

Thus, this paper briefly reviews the concept of grammar and the major issues related to the communicative approach to grammar teaching. And then, the answer to the issued topic about whether grammar teaching can be approached in the communicative way will be directly illustrated. To this end, this paper will examine the implications for grammar teaching through the communicative approach based on the researched suggestion mentioned in the literature review. In brief, it will lie in the view that grammar can be taught through the communicative approach by integrating it with communicative activities depending on the teachers' teaching beliefs.

\section{LITERATURE REVIEW}

\section{A. What is Grammar?}

"What is grammar?" is issued by so many linguistics and foreign language learners. This question can be answered by starting with Ur's elaboration for the basic concept of grammar in 1988. She states that "grammar may be roughly defined as the way a language manipulates and combines words (or bits of words) in order to form longer units of meaning" (p.4). Clearly, it indicates how the acceptable meaning will be developed by the existing grammatical rules. Also, "syntax and morphology" are considered as the "two fundamental ingredients" in Grammar (Batstone, 1994, p.4). These two ingredients can be combined together as they determine how words can be organized to form a sentence in a grammatical way (ibid). Furthermore, Batstone (1994) also emphasizes that the two factors will help learners acknowledge the grammatical forms properly so that they are able to express their meaning in an accurate way. Hence, this perception reveals the fact that language structure is governed by the regular language forms, providing language learners with the instruction to identify how grammatical structure will be formed.

A similar understanding is put forward by Swan (2005). He points out that most dictionaries often present the definition of grammar as "the rules for combining words into sentences" (p.60). Moreover, he argues this statement is incomplete as it does not explicitly explain the functions of the rules in the sentence and the reasons for people to use the rule in the language. According to his argument, this definition will affect language learners' understanding on the natural grammar learning process as they might not have a good sense of what accurate grammar is. Therefore, he ascertains that "grammar is essentially a limited set of devices for expressing a few kinds of necessary meaning that can not be conveyed by referential vocabulary alone" (Swan, 2005, p.61). Accordingly, it implies the meaning of sentences is realized by the existing rules of grammar rather than mere interpretations of single words in the sentences.

Additionally, Roberts (1998) exerts the emphasis on the specific scope of grammar in the foreign language learning.

Traditional grammar has rarely, if ever, served as an object of study for its sake; rather, it has been used as tool intended to facilitate practical but accurate mastery of the mother tongue and of foreign language (p. 146). 
It underlies the fact that the grammar plays the essential role in the language learning process, not only in the native language learning but also in the foreign language learning. Grammar learning will help language learners have a better understanding in the knowledge of language and then applying the language structure accurately in their language use. Thus, in a sense, the perceptions toward grammar can be described as an effective way through which learners can deepen their understanding of language. Also, they will know how to put words in a grammatically correct way. Thereby, a logical sentence with accurate linguistic rules will be generated and the acceptable meaning can be expressed ultimately. Hence, it can be concluded that grammar can be seen as the indispensable element in the language learning.

\section{B. Issues in the Grammar Teaching in the Foreign Language Context}

1. Grammar acquisition and noticing

As the Universal Grammar theory raised by Chomsky suggests, "learners are learning aspects of grammar that we are not teaching them", in addition, "learners have unconscious knowledge of grammar systems which we, as teachers, are often unaware of" (Shortall, 1996, p.38). Clearly, this hypothesis shows that learners' insight to acquire grammar through understanding the scope of language forms in an unconscious way rather than explicit learning process.

The similar belief has also been discussed by Richards (2002). He says some researchers claim that language learners have the 'innate ability' to understand the framework of 'grammatical variables', such as the grammatical structure, the tense, the gender, etc (p.42). However, based on these statements, he then attempts to show his own opposite attitude and states his own beliefs about grammar. It can be reported that language learners might have better understanding of the foreign language structure when they are taught with grammatical forms in an explicit way (ibid). Also, language learners have to be instructed for mastering the knowledge of grammatical structure when they attempt to acquire the formal foreign language (ibid).

It is worth noting there are four stages of grammar acquisition mentioned by Richards (2002), i.e "noticing, discovering rules, accommodation and restructuring, experimentation" (p.42-43). His perception is inspired by SLA researchers' declarations (e.g. Schmidt, 1990; DeKeyser, 1998; VanPatten, 1993; Skehan, 1996; Tarone \& Liu, 1995 cited in Richards, 2002, p.42-43). These processes about the grammar acquisition shows that how learners acquire the grammar in the foreign language context. All these assumption indicate that language input and output should be involved to facilitate the grammar acquisition process (Richards, 2002). It assumes that the whole grammar acquisition process will help language learners develop their 'interlanguage' system in some way (Richards, 2002, p.42). Hence, under this ground it can be hypothesized that learners' interlanguage development will be facilitated by the receptive and productive approach, providing that grammatical rules will be instructed for them to apply it in their expression of meaning in appropriate way.

According to the acquisition process, Schmidt and Frota (1986 cited in Richards, 2002, p.42) point out learners can produce new forms that they have previously noticed in the language used by people talking to them. It indicates that language learners will identify the language forms instructed by people who make them notice the grammar in the language. However, Richards (2002) states that learners' acquisition of grammar can not only be approached in a conscious way. He, for instance, argues that it can also be processed by instructing language learners to discover the grammatical rules unconsciously. Therefore, in light of the grammar acquisition process, the major issue in grammar study is oriented on the debate about explicit or implicit grammar teaching. In other words, how grammar can be taught is one of the focuses in grammar research.

2. Explicit grammar teaching

With the formal instruction to language teaching highlighted by Ellis (1994), the distinction of explicit and implicit instruction to grammar teaching can be identified. It claims that language learners will be exposed to the implicit instruction in which learners are provided with the chances to induce the language forms from the certain example in the context (Ellis, 1994). In addition to the explicit instruction, learners will be provided with specific grammatical rules and then practice how to use it in some way (ibid). Similarly, the issues about whether grammar should be taught inductively and deductively are also related to Ellis's focus (Roberts, 1998).

According to these debated issues, a number of studies have been conducted to seek out which approach to grammar teaching is the most effective one. However, most comparative studies related to these issues in the 1960s and 1970s did not show considerable differences between the success of explicit and implicit approach to grammar teaching (Ellis, 1994). It is worth mentioning that one exception of the findings done by Von Elek and Oskarsson (1975) (ibid). They found that many explicit methods were better than implicit methods, but the study only showed the benefit of explicit methods was only for adults and very intelligent teenagers (ibid).

In addition, Seliger (1975) found that adult ESL learners who studied in the United States have deepened their knowledge of rules when they are involved in the explicit grammar instruction (ibid). Furthermore, some empirical studies provide the evidence to support the effects of grammatical instructions with specific target language forms (e.g. Cadierno, 1995; Doughty, 1991; Lightbown \& Spada, 1990). These studies indicate that grammatical instruction will promote foreign language learners' achievements in accuracy. According to these empirical studies, hence, it shows the explicit grammar teaching would play an importance role in the foreign language classroom.

Considering the above issues, it is necessary to illustrate the supporting ideas about the implicit instruction. The assumptions are inspired by Chomskyan "internalize grammar", which advocates children can acquire grammar naturally with "random exposure" to the target environment, in some sense, like their acquisition process of mother 
tongue (Krashen and Terrel 1988 cited in Roberts, 1998, p.147-149). Thus, it indicates that grammar teaching can be processed in an inductive way. Additionally, some researchers argued that grammar translation method through explicit instruction would not provide learners' opportunities to be exposed to the target language in the traditional classroom (Roberts, 1998). However, inspired from Newmark and Reibel (1969), Roberts (1998) demonstrates his opposite view about the implicit grammar teaching. He says these two researchers have put their own theory about deductive grammar teaching into practices through a 'minimal language-teaching programme' (p.149). The eventual finding places the plain view that grammar can be taught and learnt in a deductive way (Roberts, 1998). Language learners will have the conscious awareness of language forms and understand the relationship between the various grammatical structures (ibid).

To that extent, R. Ellis (1994) notes N. Ellis's finding (1991) and presents clear elaboration of these two instructions. He concludes that being taught explicitly, language learners can have better understanding of the scope of grammar rules, but unfortunately, they can not use the grammatical rules more accurately when they are allowed to identify the language forms. Yet, through implicit instruction, it reflects the risk that language learners are unsure about the certain rules in the language. Therefore, based on the mentioned constraints, we may not recently draw the conclusion about the supportive view on the explicit grammar teaching or implicit grammar teaching.

\section{Discussions in Communicative Approach to Grammar Teaching in the Foreign Language Context}

In the previous section, it takes the overview that formal grammar teaching seems to be an effective approach to help language learners develop their explicit knowledge of grammatical rules. However, there are still some controversies over the important role of explicit grammar teaching. Regarding the pedagogical purpose of foreign language teaching with the emphasis on the language use, Roberts (1998, p.150) noted Prabhu's view as 'teaching formal grammar or teaching grammar formally is neither necessary nor useful'. Other researchers (e.g. Cook, 1991; Dulay, et al, 1982; Schwartz, 1993) also argue that formal instruction does not play the indispensable role in the grammar teaching, which can be founded in Nassaji and Fotos (2004).

Additionally, Krashen (1993) argues that the grammar learning through the focus on explicit language forms can not develop language learners' competence in the manipulation of language. On the similar ground, Truscott (1998) also argues explicit grammar instruction only focuses on instructing the language rules so that learners' "genuine knowledge of language" may not be developed (p.120). For instance, he also claims that this kind of teaching method can not develop language learners' ability in dealing with the spontaneous communication in the certain context (ibid). Significantly, Lightbown and Spada (2006) illustrate that traditional grammar teaching through focusing on language forms fails to develop language learners' ability in using foreign language accurately and fluently.

All these studies show the arguments on the important values of traditional grammar teaching in an explicit way. Considering from this angle, while, researchers (e.g. Krashen, 1999; Truscott; 1998; Nassaji \& Fotos, 2004) suggest that grammar teaching should be focused on the "form-based instruction" by presenting grammatical forms unconsciously, in which learners' skills in the mastery of foreign language will be promoted by grammar drills and practice. They also state language learners' needs for communicative purposes should be addressed through this kind of teaching method. In addition, inspired by Cook's (1991, p.28-29) discussion about the teaching learners formal grammar, 'input materials' and 'consciousness raising' activities should be taken into account in a direct way, in which learners will not only be instructed to focus on the form but also focus on the language content. Thus, on the basis of these assumptions, it leads to the reconsideration of the grammar teaching in the L2 classroom and rests in the fact that communicative approach involved with materials or certain activities to grammar teaching have been indirectly initiated.

In fact, over the centuries, second language educators have put forward the alternated teaching approaches to foreign language teaching. These approaches should emphasis on instructing language learners to analyze the element in the language and then have them acknowledge the knowledge of language by using it effectively. However, an anti-traditional approach to grammar teaching has been initiated. As Larsen-Freeman (1991, p.279) mentioned Widdowson's (1978) advocate, there is 'the rise in the popularity of more communicative approaches which emphasize language use over rules of language usage', but "loss of the popularity of the Chomsky-inspired cognitive code approach" which focuses on instructing language learners to have the language practice in "analyzing structures and applying rules".

Considering the basis of these assumptions, thus, communicative language teaching and communicative approach play dominated roles in stimulating foreign language learners' needs for communication (Larsen-Freeman, 1991). Also, Thompson (1996) points out foreign language learners who are involved in the communicative context will discover the grammar in the new language and understand its functions. Through the communicative language teaching, learners will be trained to talk about the aspects they have learned rather than merely notice it from teachers (Thompson, 1996). Therefore, the communicative language teaching occurred around 30 years until recent time, on the grounds that teaching grammar does not only have language learners' focus on acquiring the language forms, but also have them know how to apply it in their communication.

The declarations in communicative language teaching illustrate that this kind of new approach will enhance foreign language learners' competence in using the target language they have acquired effectively. However, learners' accurate mastery of foreign language has also been questioned by second language researchers. Accordingly, Ellis (1994) ascertains that language learners may not obtain the specific types of target language knowledge and skills (e.g. 
speaking, writing) through communicative approach to grammar teaching. Also, Munby (1978) and Odlin (1994) concluded other researchers' discussions and point out the negative side of communicative language teaching as it often neglects the emphasis on the relevance and meaningfulness in the grammar structures. It can be seen that the values of communicative approach to grammar teaching have been identified, but the constraint in that area has also been overviewed in some sense.

\section{Researched Suggestions for Communicative Approach to Grammar Teaching in the Foreign Language Context}

The illustrated points on whether language forms and accuracy or meaning and fluency are concerned in the communicative approach to grammar teaching. In light of the goals of second language teaching, it aims to enable learners to use language for communicative purpose and develop language learners' communicative competence. Yet, it seems to be challenging for language teachers who are working in the foreign language context.

In countries like China, for example, the classroom size is so large, roughly ranged in 30-40 students, which it is impossible to provide each student a chance to perform communicatively in the target language classroom. That is to say, students have few opportunities to perform communicative activities and experience form-focused grammar teaching. Through reconsideration of education policy by Chinese Education Ministry, curriculum of English as a foreign language for the school has been changed from a traditional grammar focus to communication focus in 2002. Thus, teachers have changed their attitude from teach grammar on language forms to communicative purpose.

The evidence for these assumptions can be supported by the studies about the communicative language teaching done by Jin (2007), Liu and Shi (2007) in China. However, these studies reveal the facts that grammar teaching for communicative approach does not help to develop language learners' competence in acquiring grammar. In some other Asia countries, such as Japan, the studies done by (Browne \& Wada, 1998; O’Donnell, 2005; Sakui, 2004 cited in Mochizuki, 2008, p.12) also show that communicative teaching does not have the actual benefits in the development of foreign language learners' grammar learning. Therefore, it seems that grammar teaching through communicative approach has been done unsuccessfully in the foreign language context, such as China and Japan.

However, regardless certain contexts, there are still some suggestions for applying communicative approach provided by many linguists to balance the grammar and communication. For example, Seedhouse (1997) suggests that combing form and meaning together through communicative approach would develop language learners' communicative competence and deepen their knowledge of foreign language. For instance, many researchers claim that integrating grammar and communication together would develop language learners' awareness of communication (e.g. Doughty \& Varela, 1998; R. Ellis 1994, 2002a, 2002b, 2003; Robinson, 2001 cited in Nassaji \& Fotos, 2004, p.131). Ellis (1994, p.639) put forward two possible approaches to deal with pedagogical purpose, firstly, communicative activities should be selected specifically, aiming at drawing foreign language learners' attention from language form to the formal grammatical structure; secondly, teachers should be aware of providing learners' with 'reactive feedback' simultaneously in order to deal with their errors which would occur during the communicative performance.

Additionally, as Widdowson's (1990, p.173) extra elaboration about the communicative activities suggested, 'linguistic repetition with its necessary focus on form, and non-linguistic purpose, with its necessary focus on meaning'. Also, the communicative approach through focus on form can also be achieved by designing the specific activities with the explicit concern on language forms (Nassaji \& Fotos, 2004). These assumptions indicate that communicative approach to grammar teaching would provide the learners with a range of opportunities to focus on the accurate grammatical forms and transfer the acceptable meaning in the communication activities. Then, it also suggests that teachers should become aware of conducting appropriate ways to integrate grammar instruction with communicative input and output.

Though the communicative approach to grammar teaching with form focus has involved with some constraints to some extent, current researchers clearly have put forward constructive suggestions to deal with that problematic issues, i.e. appropriate communicative activities, teachers' reactive feedbacks, teachers' roles in the grammar teaching and so forth.

\section{IMPLICATIONS FOR COMMUNICATIVE APPROACH TO GRAMMAR TEACHING IN THE FOREIGN LANGUAGE CONTEXT}

\section{A. Adjusting Teachers' Roles in the Grammar Teaching}

According to the overview of the communicative approach to grammar teaching, it can be seen that both supportive and opposite views have been examined. Combining the communication with grammar focus seems to be challenging for many foreign teachers in the foreign language context (e.g. China, Japan). In light of the researched questions about the communicative approach to grammar teaching, the suggestions for integrating grammar with communicative activities to deal with the constraints existing in the communicative approach has been put forward by many researchers (e.g. Ellis, 1994; Nassaji \& Fotos, 2004; Widdowson, 1990). Accordingly, it indicates that teacher should hold their own beliefs about grammar teaching through communicative approach.

Based on the considerations for communicative approach to grammar teaching raised in the literature review, thus, I can hypothesize some sort of principles to guide teachers who are working in the foreign language context to process the teaching of grammar in the communicative way. Additionally, it is worth to mention that some perceptions of the grammar teaching method are also inspired by Larsen-Freeman's recommendation in 2003. 
1. Grammar teaching should be planned systematically on the grounds of learners' language level and individual differences in the specific context.

2. Grammar teaching should focus on the development of learners' ability to perform target language fluently and accurately.

3. Grammar teaching in the foreign language classroom should demand teachers' 'code switching' techniques and 'mother tongue use' considering the particular learners who are at the beginning level (e.g. Larsen-Freeman, 2003).

4. Grammar teaching can be involved with task-based and problem-solving activities, aiming at developing learners' articulated mastery of knowledge about grammar and accurate practice in the communication (e.g. Larsen-Freeman, 2003).

5. Grammar teaching should be advanced by teachers' feedback for learners' errors in the communication so that it will develop learners' ability at active mastery of grammar (e.g. Ellis, 1994).

6. Grammar teaching can also be processed by the meaning-based activities and tasks, in which learners will be provided with the immediate opportunities to apply grammatical forms in the communication activities (e.g. Larsen-Freeman, 2003).

7. Grammar teaching should be approached by providing learners with some examples of grammatical structures when teacher conduct the communicative information, aiming to make them notice the relationship of forms and meaning in the foreign language (e.g. Larsen-Freeman, 2003).

8. Grammar teaching can also be approached by switching the explicit instruction and implicit instruction effectively in the communicative practice.

9. Grammar teaching through communicative approach with communicative activities can also be done by implementing collaborative work (e.g. group work, pair works), in which learners will notice grammatical rules with the help of their counterparts.

10. Grammar teaching should take language learners' needs and interests as well.

Given by the principles mentioned above, learners' implicit and explicit foreign language knowledge will both be developed through teachers' significant roles in constructing the considerations of foreign language teaching as well as grammar teaching. Thus, the next section will specifically concern on incorporating communicative tasks and activities to process communicative approach.

\section{B. Incorporating Communicative Activities in the Foreign Language Context}

Integrating grammar teaching with communication might seem to be teachers' pedagogical perspective based on the literature discussion mentioned above. It rests in the view that teachers should be aware of the particular field of grammar pedagogy as students will be developed by applying grammar accurately in the communication. On the other hand, they also will be trained as the proficient foreign language speaker. Therefore, for the pedagogical purpose, teachers should bear in mind that selecting grammar rules to suite students' communicative needs should take the linguistic function into account. Accordingly, it reveals that how communicative activities should be implemented appropriately in the foreign language context. Thus, the perspective of incorporating communicative activities can be examined in the following part.

\section{-Activity 1}

Accordingly, communicative activities related to grammar teaching have been suggested by Ellis in 1994. It can be assumed that this activity can be done by implementing games related to problem-solving activities and grammar drills (e.g. Larsen-Freeman, 2003) in a foreign language classroom. It can also be processed by pair works or group work, in which learners will learn to notice others' acknowledgement of grammar. Using games in a communicative classroom can be considered to be feasible for foreign language teachers. Processing activities with games will expose foreign language learners to a relaxed foreign language classroom environment. Thus, games can also be applied in the grammar teaching through communicative approach. It is worth mentioning that the activity showed in Appendix 1 in which teacher can emphasize on the teaching of both forms and meaning when they teach 'perfect tense'. This would be the proper way to conduct foreign language learners to practice forms unconsciously in a communication way. In short, in designing communicative activities that provide adequate grammar knowledge, teachers should bear in mind that simply generating target language unconsciously is not enough, what is more important is making learners enjoy the activity at the same time.

\section{-Activity 2}

Incorporating activities in the communicative context plays a substantial role in foreign language teaching as it can make students be aware of both the meaning and the form of the target language (e.g. Nassaji \& Fotos, 2004; Thompson, 1991). The meaning and forms will be informed by the authentic contexts with the materials. Thereby, not only can learners identify what the speakers' roles are but also infer the time and the place of communication. Then, it makes it possible for the teacher to teacher more advanced grammar knowledge, such as relative clauses. The example showed in appendix 2 is designed to help learners induce grammar rules based on the interactive conversation which happened in a specific context. Through looking at this activity, it can be concluded that contextualized information helps learners build a sense of the relative clauses and become aware of its usage within the accurate grammatical forms. Additionally, this simplified material written for EFL learners aims to provide examples of the variety of linguistic functions in the grammar points, which will be of value in the communication. Thus, it benefits for making students identify that 
meaning can be expressed in a particular way with the help of various grammar forms. With teachers' explanation of the grammatical features by L1 (Appendix 2, e.g. Chinese), for instance, learners' foreign language accuracy will also be achieved eventually.

In brief, communicative activities designed for grammar teaching in the communicative way should take the meaning and communication focus into account. It can be hypothesized that the tailored communicative activities will provide learners with external guidance to acknowledge how grammar forms are illustrated in the language and then know how to form grammatical sentence. To that extent, it will draw learners' attention from grammatical forms to target form, in which their performance will be accessed by the identification of foreign language forms. These illustrations show that foreign language learners' focus will be moved towards the use of particular linguistic features during the communicative performance.

\section{CONCLUSION}

As the framework of literature review has suggested, the communicative approach to grammar teaching seems to be an effective teaching method as it will not only develop foreign language learners' competence in the mastery of target language but also improve their communicative competence. Though the constraints of this approach have been examined by the linguists, the suggested grammar instructions to balance the usage of grammatical forms and communication has been initiated. All these assumptions attempt to provide the basis for promoting language learners' high level of proficiency and accurate mastery of the knowledge of grammar. It shows the facts that the traditional grammar teaching approach which merely focuses on the grammatical features might be replaced by the form-based instruction through communicative approach by integrating numerous communicative activities.

Admittedly, in the communicative context, learners' awareness of the meaning-form relationships will be promoted through teachers' appropriate grammar teaching plans. Nevertheless, it also needs to mention that the process of the grammar acquisition will be affected by the language input and output. Thus, it should note that the accurate grammar forms and meaning might not be achieved instantaneously and spontaneously because of the constraints, but for instance, it will be naturally advanced in a proper setting time where learners will move toward the mastery of the knowledge of grammar.

ApPENDiX 1: An EXAMPLE OF BROAD GAME

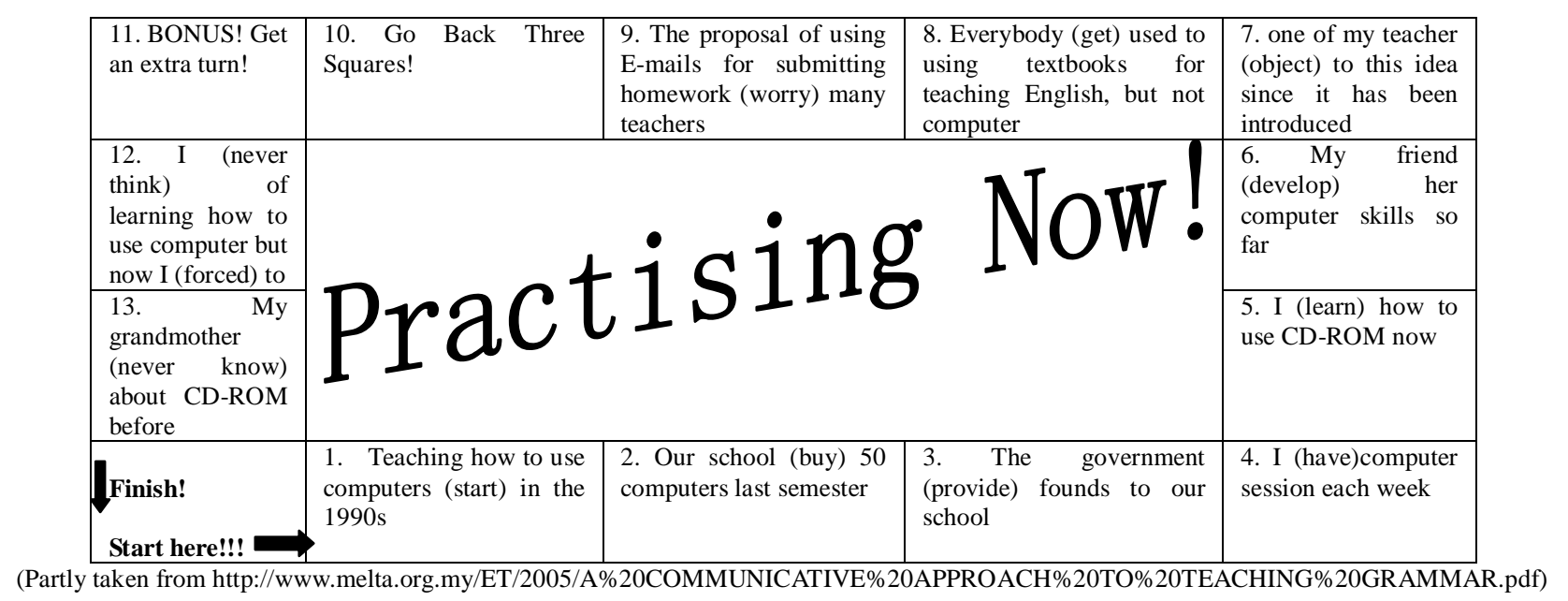

ApPendix 2: Transcript of the L2 TAPed Stimulus Seeded with Seven Relative Clauses

Kanako, her brother Ken, and their mother are at a pet shop. They are going to buy a dog today. Now they are looking at many kinds of dogs. The mother says, 'I like the dog which has long ears.' 'Which one?' Ken asks. 'I want the dog which the little girl has in her arms,' the mother answers. Ken says, 'I like the dog which has long hair.' 'Which one?' the mother asks. 'I want the dog which many people are watching,' Ken answers. The mother and Ken ask Kanako, 'What do you think, Kanako?' Kanako says, 'I can't decide! The dog which has long ears looks friendly. The dog which has long hair is beautiful.' Then Kanako looks around and finds another dog and shouts, 'I want the dog which has long ears and long hair!'

Context 1 (OS): I like the dog which has long ears

Context 2 (OO): I want the dog which the little girl has in her arms

Context 3 (OS): I like the dog which has long hair

Context 4 (OO): I want the dog which many people are watching

Context 5 (SS): The dog which has long ears looks friendly 
Context 6 (SS): The dog which has long hair is beautiful

Context 7 (OO): I want the dog which has long ears and long hair

(in Mochizuki, 2008: 35)
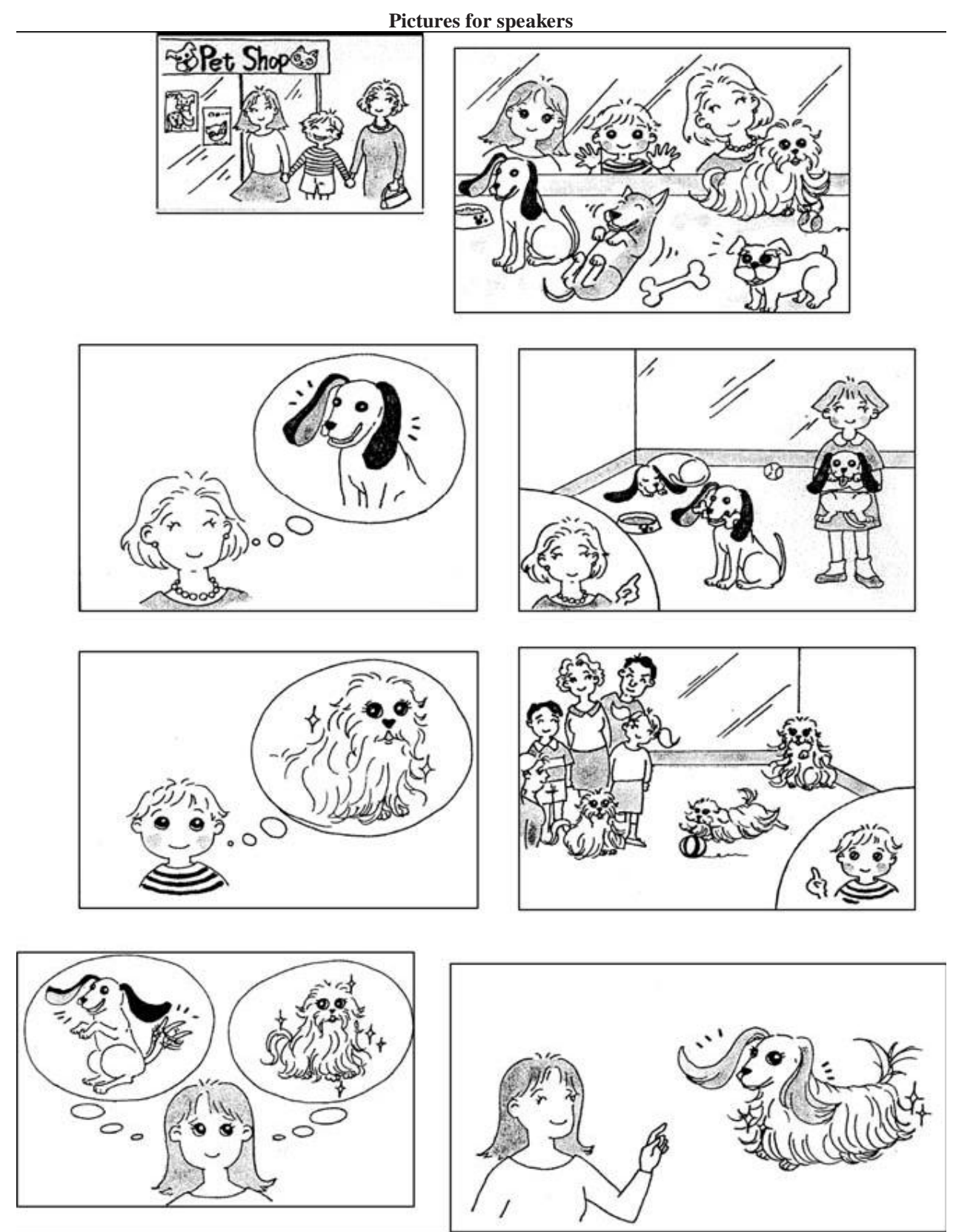

(in Mochizuki, 2008: 35)

\section{Tasks:}

Filling out the accurate forms in the blank based on grammatical forms presented above.

1. The doll is cute

The doll_ has long hair is cute

2. I want that doll.

I want that doll_has long hair

3. I like that doll

I like that doll_my Jack made

Example: explanation about the relative clause in Chinese context

(http://www.333en.com/html/yyyf/czyyyf/20071031/675.html)

一、在定语从句中, which 用来指物, 可作主语和宾语。如:

The factory which produces cars is over there.

生产汽车的那家工厂就在那边。 
The factory which I visited last year is very famous.

我去年参观的那家工厂很有名。

注意: 关系代词 that 也可以指物, 但下列情况中只能用 which, 而不能用 that.

1. 当关系代词前有介词时。如:

The company in which he works is big. ( = The company which / that the works in is big.)

他工作的那家公司很大。

2. 当先行词中有 that 时。如:

That cake which Mother made is for my birthday.

妈妈做的那块蛋糕是为我过生日用的。

3. 引导非限制性定语从句时。如:

The result of the experiment was very good, which pleased us.

实验结果很好, 这令我们十分高兴。

二、 which 引导非限制性定语从句时, 可以用来代表主句所说的整个情况或主句的某一部分内容。如:

The little monkeys wanted to catch the moon in the well, which, however, was found impossible.

那些小猴子想在井中捞月，但这是不可能的。

(which 代表句中不定式短语 to catch the moon in the well)

He passed the exam, which surprised us a lot.

他通过了考试，这使我们十分惊奇。

注意： as 引导非限制性定语从句时, 常与 which 互换, 但也有用法上的差别。

1. as 引导的非限制性定语从句可以放在主句前, 而 which 不能。如:

As is known to everyone, the moon travels round the earth.

众所周知, 月亮绕着地球转。

2. 当关系代词作非谓语动词的主语时，只能用 which .如：

She left without a word, which made her boss very angry.

她一句话也没说就走了, 这使她的老板很生气。

三、 which 的所有格有 of which 和 whose 两种形式, 两者使用时也有差别。

1. of which 修饰的名词需带定冠词 the ; whose 修饰的名词不带定冠词 the .

2. of which 的位置较灵活, 可放在被修饰名词的前面或后面; whose 只能放在被修饰名词的前面。

3. of which 只能指物; whose 可指物, 也可指人。如:

The desk whose legs are broken is mine. ( = The desk the legs of which are broken is mine.)

断了脚的那张桌子是我的。

\section{REFERENCES}

[1] Batstone, R. (1994). Grammar. Oxford: Oxford University Press.

[2] Cook, V. (1991). Second Language Learning and Language Teaching. London: Edward Arnold.

[3] Cadierno, T. (1995). Formal instruction from a processing perspective: An investigation into the Spanish past tense. Modern Language Journal, 79, 179-193.

[4] Doughty, C. (1991). Second language instruction does make a difference: Evidence from an empirical study of SL relativization. Studies in Second Language Acquisition 13, 431-496.

[5] Ellis, R. (1994). The Study of Second Language Acquisition Oxford: Oxford University Press: 630-643.

[6] Jin, Y. (2007). Adapting communicative language teaching approach to China's context Sino-US English Teaching, Vol, 4. No.10, 29-33.

[7] Krashen, S. (1993). The effect of formal grammar teaching: Still peripheral. TESOL Quarterly 27, 722-725.

[8] Krashen, S. D. (1999). Seeking a role for grammar: A review of some recent studies. Foreign Language Annals, 32, $245-257$.

[9] Larsen-Freeman, D. (2003). Teaching Language: from grammar to grammaring. Cengage Learning College.

[10] Larsen-Freeman, D. (1991). Teaching grammar. In Celce-Murcia, M. (eds.), (1991). Teaching English as a Second or Foreign Language. United States of America: Heinle \& Heinle Publishers: 279-294.

[11] Lightbown, P. \& N. Spada, (1990). Focus on form and corrective feedback in communicative language teaching: Effects on second language learning. Studies in Second Language Acquisition 12, 429-448.

[12] Lightbown, P. \& N. Spada, (2006). Two major approaches towards 'getting grammar right' in the classroom: proposals and research findings. Lecture in MA TESOL: the teaching for grammar on Applied Linguistics for TESOL. School of Education, University of Nottingham.

[13] Liu, Q, X. \& Shi, J, F. (2007). An Analysis of Language Teaching Approaches and Methods - Effectiveness and Weakness US-China Education Review, (vol. 4), 69-71.

[14] Munby, J. (1978). Communicative Syllabus Design Cambridge, UK: Cambridge University press

[15] Mochizuki, N. (2008). Balancing communication and grammar in beginning-level foreign language classrooms: A study of guided planning and relativization. Language Teaching Research 12 (1), 11-37.

[16] Nassaji, H. \& S. Fotos, (2004). Current developments in research on the teaching of grammar. Annual Review of Applied Linguistics 24, 126-145. 
[17] Odlin, T (ed.). (1994). Perspectives on Pedagogical Grammar Cambridge: Cambridge University Press.

[18] Richards, J. C. (2002). Accuracy and fluency revisited. In Hinkel, E \& S. Fotos (eds.), (2002). New Perspectives on Grammar Teaching in Second Language Classrooms New Jersey: Lawrence Erlbaum Associates, Inc., Publishers: 35-49.

[19] Roberts, J. T. (1998). Grammar teaching. In Johnson, K \& H. Johnson (eds.), (1998). Encyclopedic Dictionary of Applied Linguistics Oxford; Blackwell: 146-153.

[20] Swan, M. (2005). What is grammar? In Beaven, B (ed.), (2005). IATEFL. Cardiff Conference Selections: 60-61.

[21] Seedhouse, P. (1997). Combining form and meaning. ELT Journal. (vol. 51). 336-344.

[22] Shortall, T. (1996). What learners know and what they need to learn. In Willis, J \& D. Willis (eds.), (1996). Challenge and Change in Language Teaching. Oxford: Heinemann: 31-42.

[23] Thompson, G. (1996). Some misconceptions about communicative language teaching. ELT Journal (vol. 50). 10-12.

[24] Truscott, J. (1998). Noticing in second language acquisition: A critical review. Second Language Research 14, 103-135.

[25] Ur, P. (1988). Grammar Practice Activities. Cambridge: Cambridge University Press.

[26] Widdowson, H. G. (1990). Aspects of Language Teaching. Oxford: Oxford University Press.

Ruyun Hu, graduated from the University of Nottingham in UK, now is the lecturer of English at Chong Qing Normal University in China. Her current interests include learner autonomy, methodological and theoretical challenges in the investigation of cross-linguistic influence. 